\title{
MODEL OCENY JAKOŚCI ŚRODOWISKA ZAMIESZKANIA. ANALIZA WYBRANYCH OBSZARÓW WOJEWÓDZTWA PODKARPACKIEGO
}

\begin{abstract}
Problem jakości środowiska zamieszkania jest zagadnieniem aktualnym, którego znaczenie dostrzegane będzie także w przyszłości. Wynika to po części z narastających zagrożeń jakie towarzyszą miastom podążającym za postępem. Rozwój niesie ze sobą nowe możliwości, nadzieje na lepsze i wygodniejsze życie, ale $\mathrm{z}$ drugiej strony jest poważnym zagrożeniem dla nieodnawialnych zasobów przyrodniczych. Dziś jesteśmy świadkami ocieplającego się klimatu, coraz większego skażenia powietrza i wody. Rośnie także zachorowalność wywołana przeobrażeniami cywilizacyjnymi. W tej sytuacji prowadzenie badań nad oceną jakości środowiska mieszkaniowego współczesnego człowieka jest niezwykle ważne.

W pracy zaprezentowana zostanie metoda oceny obszarów mieszkaniowych na terenie Podkarpacia - regionu, którego atutem jest bogactwo zasobów przyrody, niskie skażenie powietrza i wody. Model oceny ma charakter interdyscyplinarny i wielokryterialny, przez co stwarza możliwość szerokiego spojrzenia na problematykę jakości środowiska mieszkaniowego, która wymaga kompleksowych analiz z pogranicza wielu dyscyplin naukowych. Do badań wykorzystano analizę urbanistyczną, analizy środowiskowe oraz analizy charakterystyczne dla geografii przestrzennej.
\end{abstract}

Słowa kluczowe: Rozwój zrównoważony, analiza urbanistyczna, badania socjologiczne, geografia przestrzenna, czynniki mikro, czynniki makro

\section{Wstęp}

Współczesne oczekiwania względem środowiska zamieszkania na miarę XXI wieku są coraz większe. Rośnie przy tym także świadomość społeczeństwa, które w większym stopniu niż dotychczas kieruje swoje potrzeby w stronę uwarunkowań wspierających zdrowe środowisko zamieszkania. I choć XXI wiek stwarza szereg możliwości nie tylko w tym zakresie co związane jest

${ }^{1}$ Justyna Kobylarczyk, Politechnika Krakowska, Wydział Architektury, Instytut Projektowania Urbanistycznego, Katedra Kształtowania Środowiska Mieszkaniowego, ul. Warszawska 24, 31-155 Kraków, Tel.602-524-529, e-mail: j.kobylarczyk@op.pl 
z postępem to $\mathrm{z}$ drugiej strony stwarza również wiele zagrożeń. Wynikają one między innymi z niekontrolowanego rozwoju miast oraz z degradacji środowiska przyrodniczego, skażenia powietrza, itd. Problemy te wyzwalają konieczność stworzenia kierunków działań naprawczych w zakresie architektury i urbanistyki, a także innych dyscyplin naukowych w oparciu o zasady harmonii oraz dbałości o dobra przyrody uwzględniające potrzeby przyszłych pokoleń. „Zachowanie równowagi pomiędzy środowiskiem przyrodniczym a zainwestowanym przez człowieka jest warunkiem koniecznym do stworzenia zdrowego, przyjaznego środowiska mieszkaniowego, w harmonii z zielonym otoczeniem, krajobrazem, w symbiozie architektury i przyrody"2.

Destrukcyjnym procesom sprzeciwia się rozwój zrównoważony - a więc rozwój, któremu towarzyszy dbałość o: zdrowie mieszkańców, dobro wspólne, świat przyrody, a także dbałość o kulturę i tradycję miejsca, jego piękno.

Zarówno postęp jak i rozwój miast powinien następować w sposób kontrolowany, przy ciągłej edukacji społecznej podnoszącej świadomość możliwych skutków pozytywnych jak i negatywnych jakie niesie ze sobą. „Rozwój miast $\mathrm{XX}$ wieku, procesy urbanizacyjne przebiegające w różny sposób i w różnym zakresie - ale na całym świecie, spowodowały, że miasto stało się jednym z najważniejszych problemów również w początku XXI wieku"3, a waz z nim jakość środowiska zamieszkania współczesnego człowieka. Człowieka dynamicznego, często zagubionego, osaczonego przez narastające tempo życia. Człowieka zagrożonego cywilizacyjnymi dysfunkcjami wywołanymi skażeniem powietrza i wody, ale także postępem doby informacyjnej.

Między innymi Europejska Rada Urbanistów w Nowej Karcie Ateńskiej (2003) zwróciła uwagę na szereg procesów i zjawisk, które mogą mieć szczególne znaczenie dla miast podążających za postępem i rozwojem. Zaprezentowana $\mathrm{w}$ dokumencie wizja miasta przyszłości opiera się w dużej mierze na dostrzeżeniu roli: przestrzeni publicznych zespalających miasto, działań naprawczych odnoszących się do stanu zdegradowanych terenów.

Miasto XXI wieku powinno być miejscem bezpiecznym, odznaczającym się indywidualnym charakterem, tożsamością i kulturą. Powinno być także miejscem o wysokich walorach estetycznych, w którym podejmuje się działania zmierzające do ochrony przyrody i dziedzictwa kulturowego, w którym dąży się do zachowania harmonii między zurbanizowanym środowiskiem, a środowiskiem przyrodniczym.

Osobnym i bardzo trudnym zagadnieniem ważnym $\mathrm{z}$ punktu widzenia trwałego i zrównoważonego rozwoju miast jest zaangażowanie społeczne w kształtowaniu zdrowego środowiska zamieszkania, środowiska wysokiej jakości promującego zdrowy i bezpieczny styl życia blisko przyrody. Niestety

\footnotetext{
${ }^{2}$ W. Seruga, Zrównoważone środowisko mieszkaniowe w dydaktyce Katedry Ksztattowania Środowiska Mieszkaniowego, Czasopismo Techniczne z.3-A, 2007, s.266

${ }^{3}$ G. Schneider-Skalska, Zrównoważone środowisko mieszkaniowe. Społeczne - oszczędne - piękne, Politechnika Krakowska, Kraków 2012, str.11.
} 
w wielu krajach społeczeństwo nie jest jeszcze na tyle dojrzałe by dostrzegać wartość dóbr wspólnych. Dla podnoszenia świadomości społecznej w zakresie kształtowania środowiska zamieszkania wysokiej jakości konieczna jest ciągła edukacja, na której efekty zmuszeni będziemy długo czekać.

Problematyka jakości środowiska zamieszkania ze względu na przeobrażenia cywilizacyjne jest i będzie w przyszłości ważnym zagadnieniem. Wiąże się bowiem z potrzebami mieszkańców, z ich stylem życia, ambicjami. Każdy z nas marzy o bezpiecznym i komfortowym środowisku, w którym ma szansę znaleźć pracę, założyć rodzinę, zawiązywać przyjaźnie.

\section{Czym jest współczesne środowisko zamieszkania?}

„Dom jest miejscem bardzo bliskim każdemu człowiekowi, do niego powraca się, jak do utraconego raju dzieciństwa, choćby tylko myślami.

Najpetniejsza, a zarazem najprawdziwsza postać prezentuje dom jako zjawisko kulturowe, posiadające oprócz postaci materialnej również duchowa, oddająca cała złożoność tradycji narodowej,

Również z jej romantycznym pojęciem domu - ojczyzny" ${ }^{\text {"4 }}$

Środowisko mieszkaniowe może być rozumiane na wiele sposobów. Czasem jest ono miastem, innym razem dzielnicą, czy też osiedlem, a nawet najbliższym sąsiedztwem.

Ponieważ struktura przestrzenna, wielkość jak i charakter obszarów mieszkaniowych jest różna trudno jest jednoznacznie zdefiniować pojęcie środowiska mieszkaniowego. Z pojęciem tym związane są nasze osobiste emocje - a więc odczucia, których nie da się zmierzyć i ocenić. Odpowiadają one za sferę niematerialną i niezwykle indywidualną. Zróżnicowania wynikają także z typologii zabudowy, sposobu zagospodarowania obszarów mieszkaniowych i ich skali, a także kontekstu miejsca, otoczenia.

Współczesne środowisko zamieszkania to „środowisko, w którym żyje i rozwija się człowiek, w którym spełnia swoje potrzeby i ambicje. Środowisko mieszkaniowe powinno między innymi spełniać wymagania jednostki w zakresie: bezpieczeństwa, identyfikacji, komfortu fizycznego i psychicznego, intymności i izolacji, komfortu bioklimatycznego, warunków do wypoczynku psychicznego i fizycznego... Na jakość środowiska mieszkaniowego składa się zarówno ogół warunków przyrodniczych, jak i korzystnych rozwiązań przestrzennych sprzyjających zdrowiu i samopoczuciu mieszkańców"5.

Dzisiejsze miasto chcielibyśmy postrzegać jako środowisko zrównoważone, a więc charakteryzujące się wysoką jakością. Pozostające w harmonii z elementami przyrodniczymi, zapewniające łatwą dostępność do przestrzeni inte-

\footnotetext{
${ }^{4}$ A. Bujak, J. L. Dobesz, Polska dom tysiącletniego narodu, Biały Kruk, Kraków 2003r., str. 7.

${ }^{5}$ G. Schneider- Skalska, Kształtowanie zdrowego środowiska mieszkaniowego. Wybrane zagadnienia, Politechnika Krakowska, Kraków 2004, s.19-20.
} 
gracyjnych, rekreacyjnych, czy też usług. Jako miejsce symbiozy tradycji i nowoczesności kreujące piękno i niepowtarzalność przestrzeni, które traktować możemy jako nasz dom - nasze miejsce do życia. Niestety współczesny obraz ośrodków miejskich i zawierających się w nich osiedli mieszkaniowych często odbiega od tych idealistycznych wizji. Charakteryzowany jest wówczas przy użyciu takich zjawisk jak: gettonizacja, wyludnienie, noclegownia, czy betonowe pustynie. Świadczy to o słabym przystosowaniu obszarów zamieszkania do potrzeb mieszkańców i postępującej degradacji przestrzeni zielonych, których często w naszym środowisku jest jeszcze zbyt mało.

\section{Wielokryterialny model oceny jakości środowiska mieszka- niowego na terenie województwa podkarpackiego}

Problematyka oceny jakości środowiska mieszkaniowego ma szczególne znaczenie dla województwa podkarpackiego, postrzeganego jako obszar pomału się rozwijający.

Do analizy małych miast Podkarpacia wykorzystano wielopłaszczyznowy oraz interdyscyplinarny model oceny stwarzający możliwość dokonania diagnozy przestrzenno - funkcjonalnej zastanego środowiska oraz sporządzenia obiektywnych wniosków przydatnych w planowaniu przestrzennym.

Podstawową metodą badawczą mającą zastosowanie w terenowych badaniach architektoniczno - urbanistycznych były analizy urbanistyczne wykorzystujące pomiary inwentaryzacyjne oraz dokumentację fotograficzną. Bardzo ważne do oceny jakości środowiska mieszkaniowego okazały się także badania ankietowe głównie stosowane w badaniach socjologicznych Trzecią wykorzystaną metodą badań były analizy studialne z pogranicza geografii przestrzennej zrealizowane na podstawie zebranych informacji oraz danych statystycznych upublicznianych przez Urzędy Miast oraz Urzędy Statystyczne.

Badania dotyczyły dwóch grup zagadnień. Oceny czynników makro oraz oceny czynników mikro. Czynniki makro odnoszące się do szerszego kontekstu - nie najbliższego obszaru mieszkaniowego tzw. sąsiedztwa, a całego regionu - województwa podkarpackiego ocenione zostały na podstawie dostępnej literatury i dokumentacji prowadzonej między innymi przez Urzędy Miast i Urzędy Statystyczne. Zebrane informacje (badania gabinetowe) prezentowały ogólne uwarunkowania regionu. W ramach analizy czynników o zasięgu makro Podkarpacie scharakteryzowano zostało pod względem: lokalizacji, czystości powietrza, czystości wód, stanu środowiska naturalnego, ekologii, warunków zdrowotnych, walorów rekreacyjnych, konfiguracji terenu, itd., a także uwarunkowań gospodarczych, takich jak: rozwój turystyki, edukacji, rolnictwa agroturystycznego, uwarunkowań komunikacyjnych, przemysłu, itd.

Badania w terenie (analiza urbanistyczna) jak i badania środowiskowe (wywiad) posłużyły do oceny czynników o zasięgu mikro. Odnosiły się one do konkretnych obszarów mieszkaniowych prezentujących różną typologię zabu- 
dowy i różny jej charakter. Pierwszy obszar (rys. 1) ograniczał się do rynku $\mathrm{z}$ historyczną, zwartą zabudową mieszkaniową $\mathrm{w}$ formie kamienic ze zróżnicowanymi usługami znajdującymi się w ich wysokich parterach. Obszar drugi (rys. 2) badań dotyczył zabudowy blokowej z przestrzeniami wspólnymi. W obszarze trzecim (rys. 3) dominowała jednorodzinna zabudowa mieszkaniowa z prywatnymi ogród-kami przydomowymi.

$\mathrm{Na}$ podstawie analizy urbanistycznej dokonano diagnozy przestrzenno usługowej zastanych obszarów zamieszkania, z określeniem ich wielkości, intensywności zabudowy oraz dostępności do usług. Ocenione zostały także warunki sprzyjające kondycji psychofizycznej mieszkańców - zdrowiu fizyczne$\mathrm{mu}$, samopoczuciu psychicznemu i mentalnemu oraz poczuciu spójności społecznej.

Warunki prozdrowotne wspierające zdrowie fizyczne mieszkańców zapewniają bliskość terenów zielonych - rekreacyjnych, wypoczynkowych i sportowych. Znaczenie ma także ich sposób zagospodarowania oraz wielkość, która powinna być dostosowana do liczby użytkowników. Istotne znaczenie mają także obiekty sportowe - ich lokalizacja, stan techniczny i przystosowanie do współczesnych potrzeb użytkowników.

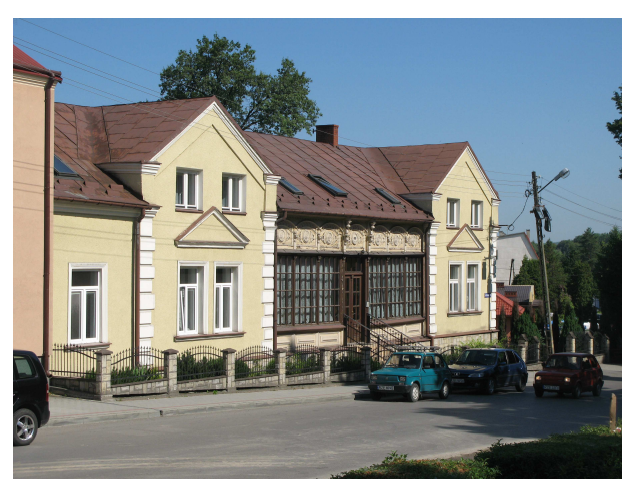

Rys. 1. Obszar I - zabudowa mieszkaniowa w rynku w Błażowej (fot. własna)

Fig. 1. Area I - housing development in the central square of Błażowa (own photo)

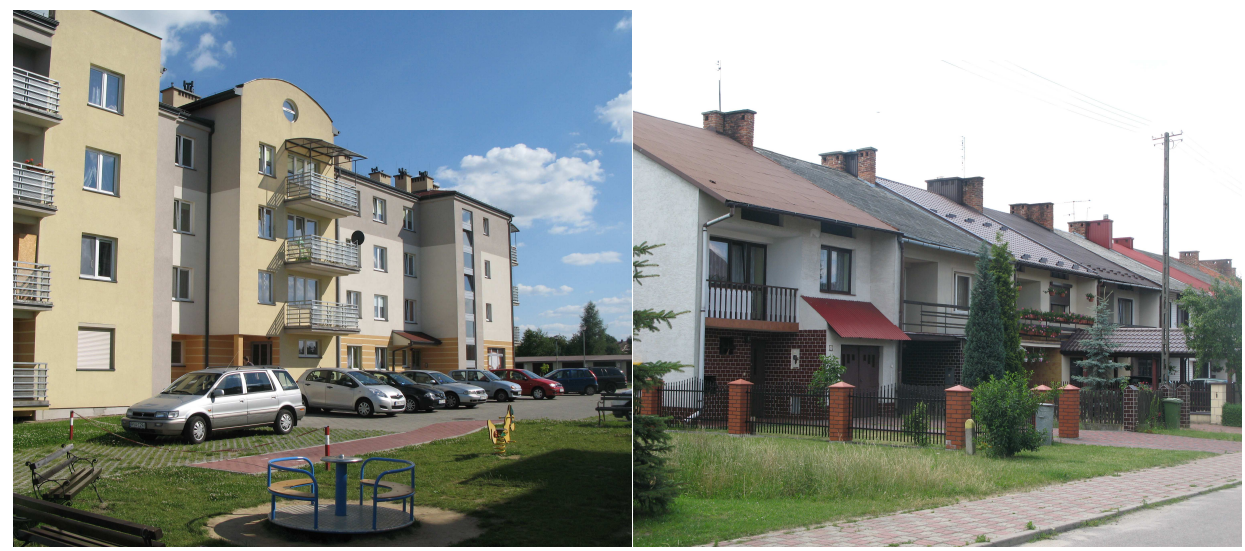

Rys. 2. Obszar II - zabudowa wielorodzinna Rys. 3. Obszar III - zabudowa jednorodzinna blokowa w Boguchwale (fot. własna) w Sokołowie Małopolskim (fot. własna)

Fig. 2. Area II - apartment housing (own photo) Fig. 3. Area III - single-family housing in Sokołów Małopolski (own photo) 
Na samopoczucie psychiczne i mentalne mieszkańców wpływ ma: wielkość przestrzeni wspólnych, odległość między obiektami o różnym charakterze i przeznaczeniu, skala obiektów, ich charakter oraz intensywność zabudowy mieszkaniowej, dostępność do usług podstawowych i ponadpodstawowych. Analizowane warunki są uznawane za jedne $\mathrm{z}$ najistotniejszych $\mathrm{w}$ świetle zasad rozwoju zrównoważonego.

Na podstawie analizy urbanistycznej oceniono warunki wspierające spójność społeczną. Ocena dotyczyła struktury mieszkań pod względem: wielkości i formy własności, wielofunkcyjności integracyjnych przestrzeni wspólnych, programu funkcjonalnego i jakości przestrzeni społecznych.

Za pomocą analizy urbanistycznej oceniono także walory kompozycyjne i estetyczne zdefiniowane przez Sherwin Green i odpowiadające za: funkcję, wygodę i komfort, ład przestrzenny i porządek, tożsamość, wizerunek miejsca oraz jego urok. Analizowano przy tym między innymi czytelność przestrzeni oraz atrakcyjność jej poszczególnych elementów (akcenty i dominanty).

Osobnym sposobem oceny czynników mikro stanowiły badania socjologiczne - badania ankietowe, w których udział brali sami mieszkańcy. Wywiad podzielony został na dwie części. W pierwszej części respondenci dokonywali oceny: stabilności miejsca zamieszkania, stanu technicznego mieszkania, elementów środowiska zamieszkania kształtujących komfortowe warunki. Oceniona została także: dostępność do usług podstawowych i ponadpodstawowych związanych między innymi z bliskością obiektów kultury, sportu i rekreacji.

W drugiej części wywiadu respondenci oceniali znaczenie 28 czynników. Wpływ poszczególnego czynnika na zamieszkiwane środowisko oceniano posługując się następującą skalą ocen: wpływ bardzo duży, duży, średni, mały, bardzo mały, żaden. Odpowiedniej ocenie przypisano także odpowiednią liczbę punktów (bardzo duży wpływ -5 , duży -4 , średni -3 , mały -2 , bardzo mały 1 , żaden - 0).

Do badań wybrano:

(1) - kompozycję układu urbanistycznego, (2) - estetykę, (3) - rodzaj, różnorodność i ilość zieleni, (4) - widok z okna, (5) - zagospodarowanie przestrzeni wspólnej, (6) - mezoklimat, (7) - doświetlenie wnętrz urbanistycznych, (8) higiena przewietrzania, (9) - dostęp do usług podstawowych, (10) - dostęp do placówek oświatowych, (11) - dostęp do ośrodków kultury, (12) - dostęp do ośrodków zdrowia i apteki, (13) - dostęp do ośrodków sportowych i rekreacyjnych, (14) - dostęp do usług komunikacyjnych, (15) - obecność placów zabaw dla dzieci, (16) - program użytkowy placów zabaw dla dzieci, (17) - obecność terenów zielonych, (18) - program użytkowy terenów zielonych, (19) - intymność i spokój, (20) - bezpieczeństwo, (21) - obecność założeń (obiektów) wodnych, (22) -obecność i wielkość podwórka, (23) - bliskość przestrzeni integralnych, (24) - obecność elementów natury, (25) - widok z ona na elementy natury, (26) - obecność zabytków lub innych cennych i unikalnych obiektów, (27) możliwość społecznego współdziałania w kształtowaniu wspólnej przestrzeni, (28) - możliwość wspólnego zarządzania środowiskiem miejsca zamieszkania. 
Oceniane elementy i czynniki wpływają w różnym stopniu na jakość środowiska zamieszkania. Osoby biorące udział w badaniu same określały intensywność ich wpływu

Zaprezentowane powyżej metody badawcze uzupełniały się wzajemnie dając szerokie spojrzenie na problem jakości środowiska mieszkaniowego. Uwzględniona została ocena własna w konfrontacji z opinią samych mieszkańców.

\section{Najważniejsze efekty pracy}

Na podstawie analiz zrealizowanych przy wykorzystaniu różnych metod badawczych o charakterze interdyscyplinarnym ocenione zostały zarówno czynniki o zasięgu makro jak i mikro. Różnią się one charakterem, zakresem terytorialnego oddziaływania, sposobem badania i możliwością ludzkiej ingerencji. Obydwie grupy oceny wspierały podstawową metodą badawczą - analizę urbanistyczną. Pozwoliły one na sporządzenie wniosków jakie mogą w przyszłości zostać wykorzystane w działaniach zmierzających do poprawy jakości środowiska zamieszkania na terenie małych miast Podkarpacia. Wyznaczono przy pomocy analizy urbanistycznej i wywiadu szczególnie ważne czynniki, elementy i zjawiska wpływające na jakość środowiska. Oceny dokonano na podstawie badań własnych oraz analizy dotyczącej preferencji mieszkańców. Oceniono przy tym także warunki wspierające prozdrowotny charakter obszarów mieszkaniowych, co wydaje się szczególnie ważne w dobie rozwijających się chorób cywilizacyjnych, coraz większego skażenie powietrza i wody.

$\mathrm{Na}$ ich podstawie można wnioskować, ze Podkarpacie pomimo tego iż zalicza się do regionów stagnacji jest obszarem, który może spełniać wymagania wysokiej jakości środowiska mieszkaniowego. Po części decydują o tym badane czynniki makro - a więc warunki przyrodnicze, niskie skażenie powietrza, a także warunki prozdrowotne wynikające z lokalizacji na terenie Podkarpacia uzdrowisk. Znajdują się one w: Iwoniczu Zdroju, Rymanowie Zdroju i na terenie Horyńca Zdrój.

Na podstawie badań można wyłonić także podstawowe problemy miast Podkarpacia wynikające między innymi z niekorzystnych rozwiązań komunikacyjnych - przebieg dróg krajowych przez ścisłe centrum niektórych miast. Nie tylko wpływa to destrukcyjnie na zabytki, na kompozycję przestrzenną podzielonego na dwie niezależne części centrum, ale także stanowi zagrożenie bezpieczeństwa.

Jednym z najpoważniejszych problemów jest brak chęci mieszkańców w zaangażowanie się we wspólne zarządzanie środowiskiem zamieszkania. Powodem jest najprawdopodobniej brak merytorycznego przygotowania mieszkańców w podejmowaniu ważnych decyzji w zakresie kształtowania obszarów mieszkaniowych wysokiej jakości, a także brak wiary w skuteczność ich działania. Konieczna w tym zakresie wydaje się edukacja społeczeństwa.

Niezwykle budujące są natomiast wyniki obrazujące pozytywny stosunek mieszkańców do zamieszkiwanego środowiska. Mieszkańcy chcą pozostać 
w swoich miastach, z którymi się utożsamiają, które traktują jako docelowe, bezpieczne zapewniające intymność i spokój środowisko mieszkaniowe.

Na podstawie wyników badań można stwierdzić, że środowisko zamieszkania wybranych miast spełnia wymagania w zakresie czynników mikro. To duża zaleta tych małych ośrodków miejskich, a także pozytywny przykład dla innych regionów. Potwierdzeniem tego jest wysoka ocena nie tylko poszczególnych czynników, ale także stabilność miejsca zamieszkania oraz preferencji środowiska zamieszkania w przypadku zmiany mieszkańców.

Obecne miejsce zamieszkania preferuje ponad $80 \%$ badanych. W przypadku konieczności zmiany mieszkania większość respondentów wybrałoby nowe miejsca zamieszkania w obrębie tego samego miasta. Świadczy to o ogólnym zadowoleniu mieszkańców z warunków mieszkaniowych jakie oferują małe miasta Podkarpacia lub braku możliwości dokonania porównania obecnego miejsca zamieszkania $\mathrm{z}$ innym na przykład znajdującym się $\mathrm{w}$ innym regionie kraju. Zdecydowana większość osób biorących udział w wywiadzie miała możliwość wyboru miejsca zamieszkania, które traktuje jako stabilne i docelowe. Można wiec przypuszczać, że mieszkańcy doceniając swoje środowisko zamieszkania będą o nie dbali i będą chcieli się z nim utożsamiać.

Podtrzymuje to wiarygodność stwierdzenia, że „małe miasta województwa podkarpackiego po najbardziej intensywnym etapie transformacji są w stanie spełnić wymagania wysokiej jakości środowiska zamieszkania, a tym samym stworzyć przyjazne warunki zamieszkania dla swoich mieszkańców”6.

\section{Literatura}

[1] Bujak A., Dobesz J.L., Polska dom tysiacletniego narodu, Biały Kruk, Kraków 2003.

[2] Kobylarczyk J., Ocena jakości środowiska zamieszkania w wybranych miastach województwa podkarpackiego po okresie „transformacji” w pierwszej dekadzie XXI wieku, Politechnika Krakowska, Kraków 2013.

[3] Schneider- Skalska G., Ksztaltowanie zdrowego środowiska mieszkaniowego. Wybrane zagadnienia, Politechnika Krakowska, Kraków 2004.

[4] Schneider-Skalska G., Zrównoważone środowisko mieszkaniowe. Społeczne oszczędne - piękne, Politechnika Krakowska, Kraków 2012.

[5] Seruga W., Zrównoważone środowisko mieszkaniowe w dydaktyce Katedry Ksztattowania Środowiska Mieszkaniowego, Czasopismo Techniczne z.3-A, 2007.

\footnotetext{
${ }^{6}$ J. Kobylarczyk, Ocena jakości środowiska zamieszkania w wybranych miastach województwa podkarpackiego po okresie ,transformacji” w pierwszej dekadzie XXI wieku, Politechnika Krakowska, Kraków 2013, str.12
} 


\section{ENVIRONMENTAL QUALITY ASSESSMENT MODEL OF RESIDENCE. ANALYSIS OF SOME PODKARPACKI AREAS}

\section{S u m m a r y}

The problem of the quality of the living environment is a current issue, the significance of which will be also perceived in the future. It is partially due to the increasing dangers that accompany the cities following progress. The development brings new opportunities, hopes for a better and more comfortable life, but on the other hand, it is a serious threat to the nonrenewable natural resources. Today we are witnessing a warming climate, as well as air, soil and water pollution. The pace of life has increased along with the number of stressful situations. There is a growing incidence of diseases induced by civilizational transformations. In this context, research concerning evaluation of the quality of the residential environment is extremely important.

This work presents method implemented for the evaluation of the residential areas in the region of Podkarpacie - region rich in natural resources, as well as low air and water pollution.

Keywords: sustainable development, urban analysis, sociological researches, area, space geographic, macro factor, micro factor

Przestano do redakcji: 01.12.2015 $r$.

Przyjęto do druku: 22.06.2015 r.

DOI:10.7862/rb.2015.46 